\title{
The Concept of Joint Property Ownership of Husband and Wife
}

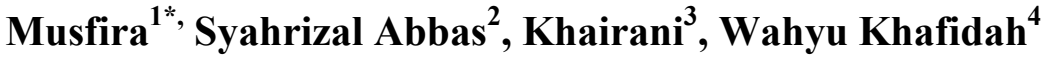 \\ ${ }^{1,4}$ Faculty of Islamic Education, Universitas Serambi Mekkah, Banda Aceh 23245, \\ Indonesia \\ ${ }^{2,3}$ Faculty of Law and Syariah, UIN Ar-Raniry, Banda Aceh 23111, Indonesia \\ *Corresponding Author: Musfira, Email: musfira1983@gmail.com
}

\begin{abstract}
Specifically, this study is the concept of joint property ownership of husband and wife. The focus of this study is important because, in the Marriage and Islamic Law Compilations, The property obtained in marriage becomes the joint property. So that, when a divorce or death occurs, each person gets half a share, in the regulation, there is no question about who produced it. In the reality of life in society, many wives work to earn a living, so it was interesting to study the different proportions in the distribution of property, in the event of a divorce. The problem of this research was how the concept of the joint property rights of husband and wife. In answering these problems, this research was carried out using the Socio-Legal Research method, by looking at the reality on the ground, to interpret joint property in changing situations. The technique of collecting data was through literature study, while the data analysis was qualitative. The findings of the study indicated that the practice of sharing assets with judges tends to use normative construction. Each of them got half a share and this was seen as an injustice, both through regulation and reconstruction of thinking in the distribution of the shared assets.
\end{abstract}

Keywords: concept, ownership, shared property, marriage, law.

\section{Introduction}

At first, it can be understood that the emergence of the institutionalization of joint property is a form of protection as well as recognition of the rights of the wife in the household. Because so far, the condition of the Indonesian people in the beginning who functions to work for a living is the husband, therefore the husband is the one who absolutely owns the property he gets. The wife works in a house that does not make money but helps her husband to prepare and manage household needs. When there is a divorce or the breakup of a marriage, the wife may not have anything as a provision for life. In this case, in order to anticipate the husband's negligence in the matter of living and the husband's lack of material attention to his wife and children, the joint property is established (Elimartati, 2018).

Joint assets, according to the Big Indonesian Dictionary (KBBI), are assets that are used together (KBBI, 2021).In Indonesian legislation, there is a shift in the meaning of joint property as a legal term. According to the Criminal Code, Chapter VI article 119, joint property occurs when a marriage is held and includes the entire joint property, as long as there are no other provisions in the marriage agreement (Raharjo, 2017). Meanwhile, according to Marriage Law No. 1/1974, joint property is property acquired during the marriage. As for the innate property of each husband and wife and the property obtained by each as a gift or inheritance, they are under the control of each as long as the parties do not specify otherwise (Djuniarti, 2016). Likewise, the definition of joint property in the Compilation of IslamicLaw has been identified as a form of syirkah. Article 1 letter (f) in book 1 mentions: assets in marriage or syirkah are assets obtained either individually or together with husband and wife during the marriage bond, hereinafter referred to as joint 
property without questioning whether it is registered in the name of anyone (Mahkamah Agung, 2011).

The changing meanings and discourses around the common property in the current context offer a unique window into understanding the broader processes and complexities associated with social change in Indonesia. So, the social change that researchers mean includes many synergistic dimensions. These include globalization, demographic transitions, mobility trends, population migration related to urbanization, development, the economy, changes in the structure of employment and uncertainty as well as economic disparities, and the contestation of norms around joint and family assets against the backdrop of existing regulations.

The issue of the concept of joint property has also been written by Sugiswati (2014). The author examined the concept of joint property ownership of husband and wife, so the focus of this study is the concept of ownership although it also requires proper regulation, the same as the legal basis.Based on what has been described above, in one family, assets are needed that meet the needs for the continuity of a marriage that is formed. The need for wealth in a marriage is one of the efforts to create a prosperous family. In a marriage that talks about the property, there must be ownership of an object, either individually or privately, it is called private property rights, while the owner of an object collectively is called joint property rights, this will be discussed in this paper. With the anxiety of the researcher seeing how important the concept of joint property ownership is, a question arises, how should the concept of joint property ownership be with husband and wife?

\section{Method}

\section{Research Design}

This study used a socio-legal research method which is multidisciplinary research that must involve legal sociology, legal history, and legal philosophy.Through this method, it can also be seen working or not, testing the effectiveness and usefulness of roles, authorities, and constructive reform efforts. This research method actually provides an effort to answer the gap between the ideal of norms and social reality. Research with this method does not only rely on norms or text-based justice efforts (legal justice) but also informs social contacts that affect the sense of justice (social justice). The types and sources of collected and analyzed data were sourced from library research with literature discussing the concept of joint property ownership rights from various sources. Meanwhile, the technique of collecting data was through literature study, while the data analysis was qualitative analysis.

\section{Results and Discussion}

Property in marriage is a combination of independent property and joint property by husband and wife. Joint assets are assets that are received by husband and wife during their married life, while the independent property is property produced by each husband and wife before marriage unless there is an agreement regarding an inheritance that will become part of the propertytogether so that it can be said that the innate property can be used as joint property (Bahari, 2016).

Based on this research, several concepts of joint property ownership of husband and wife will be described, starting from the concept of ownership. As it is known that talking about ownership in family law is not discussed in detail, but ownership is only discussed in detail when it enters the economic realm so that we currently took the concept of ownership based on economics. If in the realm of fiqh, it is included in the realm of muamalah economics, while marriage is included in the realm of muamalahfiqh, so the concept of muamalah ownership can be integrated with munakahat ownership, while the concept of 
ownership is an important part in the discussion of Islamic economics in the Islamic concept; Allah SWT is the owner, absolute over everything in the universe (Djamil, 2013). It is not wrong that ownership in marriage is very important because it involves the continuity of life in a household.

The existence of joint property in marriage does not rule out the possibility of property belonging to each husband and wife. The joint assets can be in the form of immovable objects, movable objects, and securities, while those that are intangible can be in the form of rights and obligations. Both can be used as collateral by one party with the approval of the other party, husband and wife without the consent of either party, are not allowed to sell or transfer the joint property without the knowledge of husband or wife (Tihami\&Sahrani, 2013). In this case, the husband or wife has the responsibility to maintain their joint property while in the marriage bond.

The Marriage Law and KHI both affirm and explain the existence of joint assets owned by husband and wife in addition to the property before marriage which is also recognized, as previously mentioned that the purpose of joint property in Indonesian society can be said to be in accordance with maqashidsharia, but in the mechanism The formation of the joint property automatically as adopted by the Marriage Law and KHI is not in accordance with the provisions of ownership in Islamic law, namely the cause of ownership which is justified by syara', because the marriage contract is not the cause of ownership (Rahmaniah, 2015).

The influence of the progress of the digitalization era requires answers to problems that continue to grow following current needs, even in the future. Of course, this requires tools to help solve the problem. In ownership of joint property,we used a philosophical approach. The legal philosophy approach is used to explore judges' decisions that meet the elements of justice, certainty, and expediency. Judges make legal discoveries to fill legal voids so that in the end they can be used as sources of legal reform or the development of legal science. How should a judge think in the context of legal discovery in order to produce a quality decision in every dispute resolution faced? The approach to legal science must be the main research of doctrinal law. It is not sufficient to provide a source of solving legal problems. Judges in deciding disputes donot only read the formal texts of the law normatively but must be able to reflect on the things behind the written provisions in philosophy and a sense of justice and the truth of society. Although it is not easy for judges to make an ideal decision, it must fulfill philosophical elements such as justice (philosophical), legal certainty (juridical), and the benefits of sociology at the same time. The legal philosophy approach is not only limited to the problem of legal objectives but also every fundamental problem that arises in society and requires a solution. The sociological approach to law is related to studies that highlight the influence of society on the law and the extent to which the symptoms that exist in society can affect the law.

From the judge's decision in several joint property cases, there are still variations in the legal provisions.Melia et al, 2019stated that the judge's consideration in deciding the case No. 0659/Pdt.G/2015/PA. Ska and No. 0013/Pdt.G/2015/PA. Ska, Article 35 Paragraph 1 of the Marriage Law Number 1 of 1974 and Article 97 of the Compilation of Islamic Law which reads: Property acquired during the marriage becomes joint property. Divorced widows or widowers are each entitled to one-half of the joint property as long as it is not stipulated otherwise in the marriage agreement. The results show that the distribution of joint property which is applied and refers to the Compilation of Islamic Law, especially article 97 determines that divorced widows or widowers each get one-half of the joint property as long as it is not specified otherwise in the marriage agreement

Liyantiet al (2020) analyzed Semarang religious court decisions No. 189/PDT.G/2017 PA.SMG, regarding the lawsuit for the division of joint assets mixed with congenital assets 
after divorce.In dictum No. 3, the share of each of the joint assetsis part $(25 \%)$ to be part of the Conventional Plaintiff, while the part $(75 \%)$ is to be part of the Defendant of the Convention. The results of the study indicated that the distribution of joint property in the Decision No. 189/Pdt.G/2017/PA.SMG was not in accordance with what is stipulated in the provisions of Article 97 of the Compilation of Islamic Law that "widows or widowers are each entitled to one-half of the joint property as long as it is not stipulated otherwise in the marriage agreement", because the judge has the consideration that unwritten provisions are important for included in the trial process. The same is true for the judge's decision written by Nurdin (2019). The judges at the sharia court simply consider how much the parties contribute to the joint property in the context, the problem is that the judges have a concern for the protection of women's rights and gender sensitivity then the joint property in the perspective of Islamic law has been regulated in the 1974 Marriage Law and KHI and in line with the provisions of fiqh, namely for the benefit (Maqashid Sharia).

With the above decision, the results of this research wasthe judges in deciding cases regarding the joint property have no common perception, which was caused by legal factors in Indonesia which are a mixture of the European legal system, customary law, and religious law. Using religious law because most Indonesians adhere to Islam, the dominance of Islamic law or sharia was more, especially in the fields of marriage, kinship, and inheritance. Thus, in interpreting the ownership of joint property of husband and wife, in the decision, some judges tend to use normative constructions, so that injustice was felt in society.

\section{Conclusions}

The distribution of joint property in the two regulations recognized in Indonesia, each gets one-half of the joint property as long as it is not specified otherwise in the marriage agreement. However, this can change with other considerations, the Marriage Law and the KHI both affirm and explain the existence of joint property owned by husband and wife in addition to the inherited property before marriage is also recognized.As previously mentioned, that the purpose of joint property in Indonesian society can be said to be in accordance with maqashidshariabut in the mechanism of joint property formed collectively. Automatically, as adopted by the Marriage Law and KHI is not in accordance with the provisions of ownership in Islamic law, namely the cause of ownership which is justified by syara', because the marriage contract is not the cause of ownership. Thus, the concept of joint property ownership requires new regulations, in order to answer the problems that exist in society. Regulations on the joint property appear more recently at the time of divorce. Before the divorce, there should be definite regulations so that the marriage agreement can be implemented. So, if there is a divorce, the judge can give a decision based on the marriage agreement between husband and wife.

\section{References}

Bahari, A. (2016).Tata Cara GugatanCeraiPembagianHartaGono Gini Dan HakAsuh Anak. Yogyakarta: Pustaka Yustisia

Djamil, F. (2013), Hukum Ekonomi Islam Sejarah, Teori Dan Konsep. Jakarta: SinarGrafika.

Djuniarti, E. (2016). The Law of Joint Property Reviewed from The Perspective of Marriage Law and Civil Code. JurnalPenelitian Hukum DE JURE, 17(4), 445-461.

Elimartati, (2018). Wealth in Marriage, Yogyakarta: Dialectic

KBBI. (2021). https://kbbi.kata.web.id/harta-bersamal 
Liyanti, Yulistyowati, E., \& Abib, A.S. (2020).AnalisisPutusanPengadilan Agama Semarang Nomor 189/PDT.G/2017/PA.SMG MengenaiGugatanPembagianHarta Bersama yang BercampurdenganHartaBawaan Setelah Perceraian. Semarang Law Review, 1(2), 1-15.

Mahkamah Agung RI (2011). HimpunanPerundang-Undangan yang BerkaitandenganKompilasi Hukum Islam sertaPengertiandalamPembahasannya. Jakarta: Mahkamah Agung RI.

Melia, A, M., \& Darmawan. (2019), PembagianHarta Bersama Setelah Perceraian (StudiTerhadapPutusanMahkamah Agung Nomor 597K/AG/2016, Jurnal IUS Kajian Hukum dan Keadilan, 7(3), 506-518.

Nurdin, A. (2019).PembagianHarta Bersama Dan PemenuhanHak-Hak Perempuan Di Aceh Menurut Hukum Islam.el-Usrah: Jurnal Hukum Keluarga, 2(2), 139-152.

Raharjo, S. (2017). Kitab Undang-Undang Hukum: KUHPer, KUHP, KUHAP BesertaPenjelasannya, Jakarta: BuanaIlmuPopuler.

Rahmaniah, A. (2015), Harta Bersama DalamPerkawinanDi Indonesia MenurutPerspektif Hukum Islam.Syariah: Jurnal Hukum dan Pemikiran, 15(1), 69-80.

Sugiswati, B. (2014), KonsepsiHarta Bersama dariPerspektif Hukum Islam Perdata dan Hukum Adat. Jurnal PERSPEKTIF, 19(3), 201-211.

Tihami \& Sahrani, S. (2013), FiqihMunakahat Kajian Fiqih Lengkap. Jakarta:Rajawali Pers 